\title{
French reforms should go further
}

Sir - Your coverage of the proposed reforms of French university and medical research (INSERM) and, in particular, the resistance of the universities, INSERM and CNRS to the changes suggested by Claude Allègre, the Minister of Education and Research, while accurate so far as it goes, does not mention the main factor at stake (Nature 393, 97, 102 \& 106; 1998).

The main thrust of the reforms proposed by Allègre is obviously the attempt to break, or at least reduce in French academia, the power of the corporate system, which has evolved naturally, as in other (particularly Latin) countries, from the family to the clan and finally the professional interest groups. Les grandes écoles are just the tip of an iceberg of overlapping circles of influence at all levels that, as in many other professions, are an overwhelming preoccupation of French scientists and professors.

At a recent meeting for the graduating class of one of the main lycées of Paris, two students of biology were among the professionals invited to be questioned about careers. One student had been at a grande école and his classmate at a university. The former was full of assurance and the latter slightly apologetic, but both agreed that being at a grande école increases by a factor of about ten the chance of being 'selected' at the Pasteur Institute. 'Grande école' not only means being taught by an elite of professors, after up to three years of painstaking preparative classes to pass admission exams, but also is the chance to win the race for a place that gives security for life: a salary up to the end of studies and thereafter the protection of the 'old-timer' club.

Before a student knows how to hold a pipette, the future chemist or biologist knows that he or she has to choose the strongest possible 'school' or 'patron' to protect his or her place in the corporate system. This may end up taking at least 30\% of a scientist's time, and up to $80 \%$ of time (including teaching) for a professor who may have to pay back many accumulated debts of assistance received.

The 'democratic' commissions de spécialistes that govern academic research in France are indeed elected in part, but of course, in addition to giving loyal service to the community, they also enable the corporate system to work in a political sense. Meeting in Paris, the same people distribute nationwide positions and money on an annual basis, and also judge research, with no direct input from independent or foreign experts. In the worst case, this leads to inhouse intellectual censorship which is why, in the life sciences at least, much of the originality of research is crippled. Since there is no time for in-depth analysis, anyone with an unconventional idea is easily considered a pretentious crackpot - unless supported by a 'patron' accepted within the system. Originality and international recognition have little value within the corporate system.
Another handicap of French science is that hundreds of the best scientists have to devote endless hours to evaluating the others, a most serious social game - one's students, colleagues and possibly one's own careers are at stake. It is no wonder that Allègre, wishing to break the impact of networks carefully built up over so many years and instead have scientists competing solely by the criteria of international scientific and economy-oriented standards, has met so much resistance.

Of course gradual change is necessary, but attacking just les grandes écoles is only paying lip-service to the problem. Put bluntly, in France, the evaluation of academic and scientific achievement should be strictly separated from the distribution of positions and funds; and the biannual auto-evaluation of scientific achievement by a 'commission' should be replaced by site visits every three to four years, allowing enough time (and means) to justify a project without interference, and done by independent specialists, at least $30 \%$ of whom should be from outside France. Some successful attempts at such a system are already functioning, for example the ATIPE boards of the CNRS, which fund young laboratory leaders.

\section{Klaus Scherrer}

(Directeur de Recherche, CNRS, Paris) Institut Jacques Monod, 2 Place Jussieu, F-75251 Paris Cedex 05, France e-mail:scherrer@ijm.jussieu.fr

\section{Deceptive appearance}

Sir-Hesse-Honegger's handwork is, as an aesthetic indicator of environmental pollution as described in Martin Kemp's Art and Science article, visually very attractive but may leave "corners where dark questions lurk" in areas other than those he mentions (Nature 392, 555; 1998).

The near-field of Chernobyl, Three Mile Island, and the "Chernobyl trails" in Sweden and Switzerland have very little in common radiologically, with exposures ranging from a fraction of natural levels to a thousandfold of normal. Finding consistent teratogenic effects in organisms generally known for low radiation sensitivity may have to do with poor control of important environmental parameters such as temperature during organ formation in these species. Twelve years after Chernobyl, the merits of such an assay on "radiationmutated" bugs could have been scrutinized easily by blinding, that is, by separating bug collection and morphological assessment.

In the absence of controls, this kind of superficially convincing science may suggest that the Earth is flat, or produce even less benign claims. Aesthetic hypotheses and even politics should similarly not be absolved from critical analysis, otherwise one is not obliged to accord them any importance outside the realm of aesthetics. I hope Nature will maintain its distinction between good and bad science; there is no room in between for nice (-looking) science. Werner Burkart

BfS/Institute for Radiation Hygiene,

Ingolstaedter Landstr. 1,

D-85764 Oberschleißheim, Germany

\section{EastGermans succeed}

Sir - I was disappointed by the portrayal of east German scientists in your recent article on neuroscience research in Magdeburg (see Nature 393, 725; 1998). Having worked as a doctoral student in the Institute for Neurobiology (IfN) in Magdeburg between January 1993 and November 1996 — the first non-German westerner to do so - I feel well placed to comment.

You give the impression that, during the communist period, all east German scientists were either working for the Stasi secret police, or were uncreative or unproductive. But the publication records of IfN's departments during the five years after the fall of the Berlin Wall reveal that the department with the most impressive record was the one led by an east German; it contained several east German scientists. The most successful research group in the institute was led by an east German.

I would also like to point out that the only article produced by the IfN that has appeared in Nature was co-authored by an east German (Frey and Morris, Nature 385, 533-536; 1997), and that east German doctoral students compare very favourably in their grades for their theses with the "young, self-confident west German graduate students" that you describe. Ritchie Brown

Physiology II, Heinrich-Heine-Universität, POB 101007, D-40001 Düsseldorf, Germany 